\title{
Daya prediksi laba dan aliran kas (Studi empiris pada perusahaan manufaktur di Bursa Efek Indonesia periode 2005-2009)
}

\author{
Joni \\ Universitas Kristen Maranatha Bandung, Jawa Barat \\ Jl. Prof Drg Suria Sumantri 65. Bandung \\ Email: asiung_06@yahoo.com
}

\begin{abstract}
This study provides information on predictive ability of annual earnings and cash flow from operation numbers. We obtained a sample of 42 BEI (Bursa Efek Indonesia) listed companies and 168 observation, year-end firms from 2005 to 2009. We find that both cashflows and earnings numbers have substantially predictive ability for future cashflows. Furthermore, this study documents that cashflows numbers have more predictive ability for future cashflows than earnings and the result are robust.
\end{abstract}

Keywords: Earnings, Earnings and Cashflows Prediction, Cashflow.

\section{Pendahuluan}

Informasi memiliki manfaat/ nilai apabila informasi tersebut mampu mempengaruhi keputusan para pemakainya. Informasi juga akan bermanfaat apabila informasi tersebut mampu menambah pengetahuan dan keyakinan para pemakainya. Oleh karena itu, FASB (Financial Accounting Standards Board) dalam SFAC (Statement of Financial Accounting Concepts) No.2 menyatakan bahwa informasi akuntansi bermanfaat/ bernilai apabila informasi tersebut memiliki nilai relevansi dan reliabilitas yang tinggi. Nilai relevansi menyatakan mengenai kemampuan informasi untuk mempengaruhi keputusan para pemakai (investor, kreditor, dan pemakai lainnya), sedangkan nilai reliabilitas yang tinggi menyatakan mengenai kemampuan informasi untuk memberi keyakinan bahwa informasi tersebut benar atau valid.

Salah satu unsur utama yang membentuk nilai relevansi informasi akuntansi adalah nilai prediksi. Nilai prediksi informasi akuntansi merupakan kemampuan informasi tersebut untuk membantu pemakai dalam memprediksi hasil suatu kejadian di masa yang akan datang. Banyak studi yang menunjukkan bukti empiris mengenai kemampuan prediksi informasi akuntansi, baik informasi laba maupun aliran kas dalam memprediksi aliran kas di masa yang akan datang.

Beberapa studi menemukan bahwa laba memiliki daya prediksi yang tinggi terhadap aliran kas di masa yang akan datang. Greenberg et al. (1986), Finger (1994), Lorek dan Willinger (1996), Cheng et al. (1996), Burgstahler et al. (1998), Supriyadi (1999), DeFond dan Hung (2001), Kim dan Kross (2002) menemukan bahwa laba mempunyai kemampuan prediksi yang baik terhadap aliran kas masa depan.

Selain laba, aliran kas sekarang juga menunjukkan daya prediksi yang tinggi terhadap aliran kas di masa yang akan datang. Bowen et al. (1986), Finger (1994), Cheng et al. (1996), Burgstahler et al. (1998), Supriyadi (1999), DeFond dan Hung (2001), Kusuma (2003) menemukan bahwa aliran kas merupakan pre-

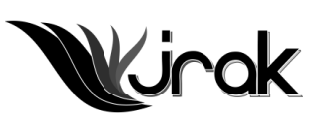

Jurnal Reviu Akuntansi dan Keuangan

ISSN: 2088-0685 Vol.1 No. 1, April 2011 Pp 39-48 


\section{Daya \\ Prediksi \\ Laba dan \\ Aliran Kas}

40 diktor yang baik terhadap aliran kas masa depan khususnya untuk periode prediksi satu atau dua tahun.

Beberapa peneliti lain juga menguji kemampuan prediksi dari komponenkomponen aliran kas terhadap aliran kas masa depan. Riyanto (2004) dalam penelitiannya menunjukkan bahwa komponen-komponen aliran kas aktivitas operasi (penerimaan dari pelanggan, pembayaran kepada pemasok dan karyawan, pembayaran bunga, pembayaran pajak, dan pembayaran lain-lain) merupakan prediktor yang baik atas aliran kas operasi mendatang (satu sampai dengan tiga tahun ke depan). Bandi dan Rahmawati (2005) menemukan bahwa komponen aliran kas (operasi, pendanaan, dan investasi) merupakan prediktor yang baik atas aliran kas masa depan.

Beberapa bukti empiris ini menunjukkan hasil yang tidak konsisten mengenai kemampuan prediksi antara laba dan aliran kas. Beberapa studi menunjukkan bahwa laba memiliki daya prediksi terhadap aliran kas di masa yang akan datang yang lebih tinggi dibandingkan dengan aliran kas. Sedangkan bukti yang lain menunjukkan bahwa aliran kas memiliki daya prediksi terhadap aliran kas di masa yang akan datang. Greenberg et al. (1986), Rayburn (1986), Wilson (1986) menyimpulkan bahwa laba mempunyai kemampuan prediksi lebih baik dibandingkan aliran kas. Lorek dan Willinger (1996), Sloan (1996) juga menemukan bahwa laba mempunyai kemampuan prediksi lebih baik dibandingkan aliran kas masa depan dengan menggunakan data kuartalan. Kemudian Dechow et al. (1994, 1998), Landsman dan Maydew (2002) menemukan bahwa laba memiliki kemampuan prediksi yang lebih baik dibandingkan dengan aliran kas operasi.

Tetapi Bowen et al. (1986) tidak menemukan bahwa laba dapat memprediksi aliran kas masa depan lebih baik dibandingkan aliran kas. Finger (1994) menemukan bahwa aliran kas justru lebih baik dibandingkan laba dalam melakukan prediksi dengan masa prediksi yang relatif pendek (satu sampai dua tahun), tetapi laba dan aliran kas memiliki kemampuan prediksi yang sama untuk jangka waktu yang lebih panjang. Dengan sampel yang lebih besar, Burgstahler et al. (1998) juga menemukan bahwa aliran kas mempunyai kemampuan prediksi yang lebih baik dibandingkan laba. Kemudian DeFond dan Hung (2001) mengindikasikan bahwa laba secara signifikan memiliki sedikit kemampuan prediksi dan aliran kas secara signifikan memiliki kemampuan prediksi yang lebih besar untuk memprediksi aliran kas masa depan.

Berdasarkan uraian fenomena dan bukti empiris sebelumnya, maka penelitian ini memiliki beberapa tujuan yang secara umum saling terkait. Pertama, menemukan bukti empiris mengenai daya prediksi laba terhadap aliran kas di masa yang akan datang. Kedua, menemukan bukti empiris mengenai daya prediksi aliran kas terhadap aliran kas di masa yang akan datang. Ketiga, menemukan bukti empiris mengenai perbandingan kemampuan prediksi antara laba dan aliran kas.

\section{Pengembangan Hipotesis}

\section{Kemampuan Prediksi Laba}

Beberapa studi menemukan bahwa laba memiliki daya prediksi yang tinggi terhadap aliran kas di masa yang akan datang. Greenberg et al. (1986) menemukan bahwa laba mempunyai kemampuan prediksi yang baik terhadap aliran kas masa depan. Finger (1994) menemukan bahwa untuk jangka waktu yang lebih panjang, laba mempunyai kemampuan prediksi yang baik terhadap aliran kas masa depan. Lorek dan Willinger (1996) menemukan bahwa laba mempunyai kemampuan prediksi yang baik terhadap aliran kas masa depan dengan menggunakan data kuartalan. Cheng et al. (1996) juga menemukan bahwa laba memiliki daya prediksi yang tinggi terhadap aliran kas masa depan. Kemudian Burgstahler et al. (1998) menemukan bahwa laba mempunyai kemampuan prediksi yang baik terhadap aliran kas masa depan. Sedangkan Supriyadi (1999) menemukan bahwa laba memiliki sedikit kemampuan prediksi dalam memprediksi aliran kas masa depan. DeFond dan Hung (2001) juga menemukan bahwa laba secara signifikan memiliki 
sedikit kemampuan prediksi untuk memprediksi aliran kas masa depan. Kim dan Kross (2002) menyatakan bahwa hubungan antara laba dan aliran kas masa depan tetap menguat.

Berdasarkan landasan teori dan hasil penelitian sebelumnya, maka dapat dirumuskan hipotesis alternatif pertama yang dinyatakan sebagai berikut:

$\mathrm{H}_{1}$ : Laba mempunyai kemampuan prediksi terhadap aliran kas operasi masa depan.

\section{Kemampuan Prediksi Aliran Kas}

Aliran kas sekarang menunjukkan daya prediksi yang tinggi terhadap aliran kas di masa yang akan datang. Bowen et al. (1986) menemukan bahwa aliran kas merupakan prediktor yang baik terhadap aliran kas masa depan khususnya untuk periode prediksi satu atau dua tahun. Finger (1994) juga menemukan bahwa aliran kas dalam jangka pendek adalah prediktor yang baik terhadap aliran kas. Cheng et al. (1996) menunjukkan bahwa nilai tambah kandungan informasi aliran kas operasi dalam memprediksi aliran kas menunjukkan peningkatan. Burgstahler et al. (1998) menemukan bahwa aliran kas mempunyai kemampuan prediksi yang baik terhadap aliran kas masa depan. Supriyadi (1999) menyatakan bahwa data aliran kas memberikan informasi yang baik untuk meramalkan aliran kas masa depan. DeFond dan Hung (2001) mengindikasikan bahwa aliran kas secara signifikan memiliki kemampuan yang besar untuk memprediksi aliran kas masa depan. Kusuma (2003) juga menunjukkan bahwa aliran kas operasi mempunyai nilai tambah kandungan informasi dalam memprediksi aliran kas masa depan.

Beberapa peneliti lain juga menguji kemampuan prediksi dari komponenkomponen aliran kas terhadap aliran kas masa depan. Riyanto (2004) dalam penelitiannya menunjukkan bahwa komponen-komponen aliran kas aktivitas operasi (penerimaan dari pelanggan, pembayaran kepada pemasok dan karyawan, pembayaran bunga, pembayaran pajak, dan pembayaran lain-lain) merupakan prediktor yang baik atas aliran kas operasi mendatang (satu sampai dengan tiga tahun ke depan). Bandi dan Rahmawati (2005) menemukan bahwa komponen aliran kas (operasi, pendanaan, dan investasi) merupakan prediktor yang baik atas aliran kas masa depan.

Berdasarkan landasan teori dan hasil-hasil penelitian yang dipaparkan sebelumnya, maka dapat disusun hipotesis kedua sebagai berikut:

$\mathrm{H}_{2}$ : Aliran kas operasi mempunyai kemampuan prediksi terhadap aliran kas operasi masa depan.

\section{Perbandingan Kemampuan Prediksi}

Beberapa bukti empiris ini menunjukkan hasil yang tidak konsisten mengenai kemampuan prediksi antara laba dan aliran kas. Beberapa studi menunjukkan bahwa laba memiliki daya prediksi terhadap aliran kas di masa yang akan datang yang lebih tinggi dibandingkan dengan aliran kas. Sedangkan bukti yang lain menunjukkan bahwa aliran kas memiliki daya prediksi terhadap aliran kas di masa yang akan datang. Greenberg et al. (1986), Rayburn (1986), Wilson (1986) menyimpulkan bahwa laba mempunyai kemampuan prediksi lebih baik dibandingkan aliran kas. Lorek dan Willinger (1996), Sloan (1996) juga menemukan bahwa laba mempunyai kemampuan prediksi lebih baik dibandingkan aliran kas masa depan dengan menggunakan data kuartalan. Kemudian Dechow et al. (1994, 1998), Landsman dan Maydew (2002) menemukan bahwa laba memiliki kemampuan prediksi yang lebih baik dibandingkan dengan aliran kas operasi. Penelitian Barth et al. (2001) menegaskan lagi bahwa laba memiliki kemampuan prediksi yang lebih tinggi dibandingkan dengan aliran kas operasi.

Tetapi Bowen et al. (1986) tidak menemukan bahwa laba dapat memprediksi aliran kas masa depan lebih baik dibandingkan aliran kas. Finger (1994) menemukan bahwa aliran kas justru lebih baik dibandingkan laba dalam melakukan pre- 


\section{Daya \\ Prediksi \\ Laba dan \\ Aliran Kas}

diksi dengan masa prediksi yang relatif pendek (satu sampai dua tahun), tetapi laba dan aliran kas memiliki kemampuan prediksi yang sama untuk jangka waktu yang lebih panjang. Dengan sampel yang lebih besar, Burgstahler et al. (1998) juga menemukan bahwa aliran kas mempunyai kemampuan prediksi yang lebih baik dibandingkan laba. Kemudian DeFond dan Hung (2001) mengindikasikan bahwa laba secara signifikan memiliki sedikit kemampuan prediksi dan aliran kas secara signifikan memiliki kemampuan prediksi yang lebih besar untuk memprediksi aliran kas masa depan.

Beberapa penelitian di Indonesia juga telah membandingkan kemampuan prediksi kas dan laba. Supriyadi (1999) menemukan bahwa data aliran kas memberikan informasi yang lebih baik untuk meramalkan aliran kas masa depan dibandingkan dengan laba. Ia juga menegaskan bahwa laba menambah sedikit terhadap kemampuan prediksi aliran kas dalam memprediksi aliran kas masa depan. Kusuma (2003) menunjukkan bahwa laba tidak mempunyai nilai tambah kandungan informasi di luar informasi yang diberikan oleh aliran kas operasi. Aliran kas operasi mempunyai nilai tambah kandungan informasi di luar informasi yang diberikan oleh laba serta memiliki nilai tambah kandungan informasi pada saat laba mengandung komponen transitori. Cahyadi (2006) menemukan bukti bahwa laba sebagai variabel independen tidaklah signifikan dalam hubungannya dengan aliran kas sebagai variabel dependen, dibandingkan prediktor aliran kas terhadap aliran kas. Dahler dan febrianto (2006) juga menemukan bahwa aliran kas operasi lebih mampu memprediksi aliran kas operasi di masa datang ketika perusahaan melaporkan kerugian.

Berdasarkan landasan teori dan hasil-hasil penelitian yang dipaparkan sebelumnya, maka dapat disusun hipotesis kedua sebagai berikut:

$\mathrm{H}_{3}$ : Laba mempunyai kemampuan prediksi terhadap aliran kas operasi masa depan yang lebih baik dibandingkan dengan aliran kas operasi.

\section{Metode}

\section{Sampel dan Data}

Sampel penelitian diambil dari perusahaan yang terdaftar di Bursa Efek Indonesia mulai 2005 sampai 2009. Teknik penyampelan menggunakan metoda purposive, dengan ketentuan sebagai berikut:

1. Perusahaan tidak dikelompokkan kedalam jenis industri jasa keuangan. Hal ini ditetapkan karena jenis industri keuangan sangat rentan terhadap regulasi dan memiliki perbedaan karakteristik akrual dibandingkan jenis industri lainnya.

2. Perusahaan Perusahaan manufaktur yang terdaftar di BEI.

3. Perusahaan menerbitkan laporan keuangan (termasuk laporan aliran kas) secara terus menerus dari tahun 2001 sampai tahun 2009.

Data yang dibutuhkan peneliti adalah laporan keuangan tahun 2005-2009. Data diperoleh dari Pusat Referensi Pasar Modal (PRPM), Basis Data Proyek Pengembangan Akuntansi (PPA) Fakultas Ekonomi Universitas Gadjah Mada.

\section{Pengukuran Variabel Penelitian}

Pengukuran variabel dalam penelitian ini adalah sebagai berikut:

a. Laba

Laba yang digunakan adalah laba sebelum pos luar biasa dan operasi yang dihentikan. Laba ini disebut sebagai laba bersih secara agregat.

b. Aliran Kas

Aliran kas yang digunakan adalah aliran kas operasi dengan metoda langsung ataupun tidak langsung. 
Uji outlier dilakukan untuk menghilangkan nilai-nilai ekstrim pada hasil observasi. Menurut Hair et al (1998), outliers terjadi karena kombinasi unik yang terjadi dan nilai-nilai yang dihasilkan dari observasi tersebut sangat berbeda dari observasi-observasi lainnya. Apabila ditemukan outliers, maka data yang bersangkutan harus dikeluarkan dari perhitungan lebih lanjut. Dalam analisis multivariat, outliers dapat diuji dengan membandingkan nilai mahalanobis distance squared dengan nilai chi square tabel pada jumlah tertentu dan tingkat $p<0,001$ (Hair et al., 1998). Apabila nilai mahalanobis distance squared lebih besar dibandingkan nilai chi square tabel, maka data tersebut merupakan outlier sehingga harus dikeluarkan dari observasi.

\section{Pengujian Normalitas}

Pengujian ini untuk melihat kenormalan distribusi data variabel independen dan variabel dependen pada model regresi. Model regresi dikatakan baik apabila memiliki distribusi data normal atau mendekati normal. Deteksi normalitas dilakukan dengan melihat nilai skewness dari residual. Nilai z statistik untuk skewness dapat dihitung dengan menggunakan rumus:

$$
\text { zskew }=\frac{\text { skewness }}{\sqrt{24 / n}}
$$

Apabila Z hitung $>$ Z tabel, maka distribusi tidak normal dan sebaliknya.

\section{Pengujian Heteroskedastisitas}

Pengujian ini untuk melihat ketidaksamaan penyimpangan (variance) residual satu pengamatan ke pengamatan lain pada model regresi. Apabila penyimpangan residual satu pengamatan terhadap pengamatan lain berbeda, maka model regresi dikatakan heteroskedastisitas. Deteksi heteroskedastisitas dapat dilakukan dengan uji Park. Pengujian dilakukan dengan meregresikan nilai logaritma kuadrat residual terhadap variabel independen. Apabila variabel independen signifikan secara statistik dalam mempengaruhi variabel dependen, maka terdapat indikasi terjadi heteroskedastisitas.

\section{Pengujian Autokorelasi}

Pengujian ini untuk melihat korelasi antara kesalahan pengganggu perioda $\mathrm{t}$ dengan kesalahan pengganggu perioda t-1 (sebelumnya) pada model regresi. Apabila terdapat korelasi, maka terdapat masalah autokorelasi. Deteksi autokorelasi dapat dilakukan dengan uji Breusch-Godfrey, yaitu melakukan regresi dengan persamaan sebagai berikut: Res_1 = bo +b1X1 +b2X2+b3Res_2. Autokorelasi terjadi apabila variabel Res_2 secara statistik berpengaruh secara signifikan terhadap variabel dependen.

\section{Pengujian Multikolinearitas}

Pengujian ini untuk melihat korelasi antara variabel independen pada model regresi. Model regresi yang baik seharusnya tidak terdapat korelasi di antara variabel independen.

Deteksi multikolinearitas dapat dilakukan dengan melihat nilai Variance Inflation Factor (VIF) yang terdapat pada tabel Coeficients( \pm ), kolom Collinearity Statistics. Selain itu, dapat juga dilihat dari nilai Tolerance-nya pada kolom yang sama. Batas untuk Tolerance adalah 0.01 dan batas untuk nilai VIF harus kurang dari 10. Ketentuannya sebagai berikut: 


\section{Daya \\ Prediksi \\ Laba dan \\ Aliran Kas}

44

Tabel 1

Descriptive Statistics

Tabel 2

Descriptive Statistics

Tabel 3

Descriptive

Coefficients

a. Dependent Variable: LNU2
- Tolerance value $<0.01$ atau VIF $>10=$ menjadi multikolinearitas.

- Tolerance value $>0.01$ atau VIF $<10=$ tidak terjadi multikolinearitas

\section{Perumusan Pengujian Hipotesis}

Hipotesis dalam penelitian ini akan diuji dengan menggunakan analisis regresi linear. Persamaan dalam penelitian ini adalah sebagai berikut:

(1) $C F_{i, t+1}=a+b N I_{i, t}+u_{i, t}$

(2) $C F_{i, t+1}=a+b C F_{i, t}+u_{i, t}$

(3) $C F_{i, t+l}=a+b N I_{i, t}+c C F_{i, t}+u_{i, t}$

\section{Hasil Penelitian}

\section{Statistik Deskriptif}

Tabel 1 menyajikan statistik deskriptif untuk variabel-variabel dalam model penelitian. Sampel dalam penelitian ini adalah 42 perusahaan manufaktur yang terdaftar di Bursa Efek Indonesia dari tahun 2005 sampai 2009, yaitu 168 observasi. Variabel-variabel yang disajikan adalah aliran kas aktivitas operasi periode $t+1$, aliran kas aktivitas operasi periode $t$, dan laba bersih periode $t$.

\begin{tabular}{|l|c|r|r|r|c|}
\hline & $\mathrm{N}$ & \multicolumn{1}{|c|}{ Minimum } & \multicolumn{1}{c|}{ Maximum } & \multicolumn{1}{c|}{ Mean } & \multicolumn{1}{c|}{ Std. Deviation } \\
\hline LABA_0 & 168 & -103020000000.00 & 91582035931.00 & 6944070054.6 & 31937304447.58 \\
CASH_0 & 168 & -85635456035.00 & 120602000000.00 & 19683166164 & 29878111344.61 \\
CASH_1 & 168 & -85635456035.00 & 153724000000.00 & 20093879659 & 31496987174.96 \\
Valid N & 168 & & & & \\
(listwise) & & & & & \\
\hline
\end{tabular}

\section{Pengujian Asumsi Klasik}

\section{Pengujian Outlier}

Uji outlier dilakukan untuk menghilangkan nilai-nilai ekstrim pada hasil observasi. Menurut Hair et al (1998), outliers terjadi karena kombinasi unik yang terjadi dan nilai-nilai yang dihasilkan dari observasi tersebut sangat berbeda dari observasi-observasi lainnya. Jumlah observasi sebelum dilakukan uji outlier adalah 276, kemudian setelah dilakukan uji outlier maka observasi yang masih tersisa adalah 168.

\section{Pengujian Normalitas}

Hasil pengujian (Tabel 2) menunjukkan bahwa nilai skewness adalah 0.480 dan nilai Zskewness adalah 2.54. Hal ini menunjukkan bahwa Zhitung $(2.54)<\mathrm{Z}$ tabel (2.58) pada tingkat signifikansi 0.01 yang berarti berdistribusi normal.

\begin{tabular}{|l|r|r|r|}
\hline & \multicolumn{1}{|c|}{$\mathrm{N}$} & \multicolumn{2}{|c|}{ Skewness } \\
\cline { 2 - 4 } & Statistic & Statistic & Std. Error \\
\hline Unstandardized Residual & 168 & .480 & .187 \\
Valid N (listwise) & 168 & & \\
\hline
\end{tabular}

\section{Pengujian Heteroskedastisitas}

Hasil pengujian (Tabel 3) menunjukkan bahwa model penelitian tidak terdapat heteroskedastisitas karena tidak ada variabel independen yang memiliki nilai signifikan secara statistik terhadap nilai logaritma kuadrat residual (tingkat signifikansi $1 \%$.

\begin{tabular}{|rl|r|r|r|r|r|}
\hline \multirow{2}{*}{ Model } & \multicolumn{2}{|c|}{$\begin{array}{c}\text { Unstandardized } \\
\text { Coefficients }\end{array}$} & \multicolumn{2}{c|}{$\begin{array}{c}\text { Standardized } \\
\text { Coefficients }\end{array}$} & \multirow{2}{*}{} \\
\cline { 3 - 5 } & & \multicolumn{1}{|c|}{$\mathrm{B}$} & \multicolumn{1}{c|}{ Std. Error } & \multicolumn{1}{c|}{ Beta } & \multicolumn{1}{c|}{ Sig. } \\
\hline 1 & (Constant) & 45.663 & .256 & & 178.443 & .000 \\
& LABA_0 & $-3.98 \mathrm{E}-12$ & .000 & -.047 & -.499 & .618 \\
& CASH_0 & $1.080 \mathrm{E}-11$ & .000 & .118 & 1.266 & .207 \\
\hline
\end{tabular}




\section{Pengujian Autokorelasi}

Hasil pengujian (Tabel 4) menunjukkan bahwa tidak terdapat autokorelasi pada model penelitian karena koefisien parameter untuk residual lag2 (res_2) tidak menunjukkan pengaruh yang signifikan secara statistik (0.369).

\begin{tabular}{|c|c|c|c|c|c|c|}
\hline \multirow{2}{*}{\multicolumn{2}{|c|}{ Model }} & \multicolumn{2}{|c|}{$\begin{array}{c}\text { Unstandardized } \\
\text { Coefficients }\end{array}$} & \multirow{2}{*}{$\begin{array}{c}\begin{array}{c}\text { Standardized } \\
\text { Coefficients }\end{array} \\
\text { Beta } \\
\end{array}$} & \multirow[b]{2}{*}{$t$} & \multirow[b]{2}{*}{ Sig. } \\
\hline & & B & Std. Error & & & \\
\hline \multirow[t]{4}{*}{1} & (Constant) & $-4.0 \mathrm{E}+08$ & $2.2 \mathrm{E}+09$ & & -.179 & .858 \\
\hline & LABA_0 & -.002 & .069 & -.003 & -.033 & .974 \\
\hline & CASH_0 & .010 & .074 & .012 & .132 & .895 \\
\hline & RES2 & -.071 & .079 & -.070 & -.901 & .369 \\
\hline
\end{tabular}

\section{Pengujian Multikolinearitas}

Hasil pengujian (Tabel 5) menunjukkan bahwa tidak terdapat indikasi multikolinearitas pada model penelitian. Hal ini ditunjukkan dengan nilai tolerance-nya yang lebih dari 0.01 dan VIF yang kurang dari 10.

\begin{tabular}{|c|c|c|c|c|c|c|c|c|}
\hline \multirow{2}{*}{\multicolumn{2}{|c|}{ Model }} & \multicolumn{2}{|c|}{$\begin{array}{c}\text { Unstandardized } \\
\text { Coefficients }\end{array}$} & \multirow{2}{*}{$\begin{array}{c}\text { Standardized } \\
\text { Coefficients } \\
\text { Beta }\end{array}$} & \multirow[b]{2}{*}{$t$} & \multirow[b]{2}{*}{ Sig. } & \multicolumn{2}{|c|}{ Collinearity Statistics } \\
\hline & & B & Std. Error & & & & Tolerance & VIF \\
\hline 1 & (Constant) & $8.2 E+09$ & $2.2 \mathrm{E}+09$ & & 3.687 & .000 & & \\
\hline & LABA_0 & .245 & .069 & 248 & 3.536 & .001 & .690 & 1.449 \\
\hline & CASH_O & .519 & .074 & .493 & 7.027 & .000 & .690 & 1.449 \\
\hline
\end{tabular}

\section{Tabel 5}

Coefficients

a. Dependent Variable: CASH_1

\section{Pengujian Hipotesis}

\section{Kemampuan Prediksi Laba}

Tabel 6 menunjukkan hasil pengujian kemampuan prediksi laba terhadap aliran kas operasi masa depan. Hasilnya menunjukkan bahwa laba mempunyai kemampuan prediksi terhadap aliran kas operasi masa depan. Hal ini ditunjukkan melalui nilai Adjusted $\mathrm{R}^{2}$ sebesar 27,3\% dan signifikan secara statistik (0.00).

Berdasarkan hasil analisis yang telah dipaparkan sebelumnya, maka hipotesis alternatif pertama yang menyatakan bahwa laba mempunyai kemampuan prediksi terhadap aliran kas operasi masa.depan terdukung.

\begin{tabular}{|l|r|r|r|r|}
\hline Model & R & R Square & $\begin{array}{c}\text { Adjusted } \\
\text { R Square }\end{array}$ & $\begin{array}{c}\text { Std. Error of } \\
\text { the Estimate }\end{array}$ \\
\hline 1 & $.522^{\mathrm{a}}$ & .273 & .268 & $2.694 \mathrm{E}+10$ \\
\hline
\end{tabular}

\begin{tabular}{|ll|r|r|r|r|r|}
\hline \multirow{2}{*}{ Model } & & \multicolumn{2}{|c|}{$\begin{array}{c}\text { Unstandardized } \\
\text { Coefficients }\end{array}$} & $\begin{array}{c}\text { Standardized } \\
\text { Coefficients }\end{array}$ & & \\
\cline { 2 - 4 } & & \multicolumn{1}{|c|}{ B } & Std. Error & \multicolumn{1}{|c|}{ Beta } & \multicolumn{1}{c|}{ t } & \multicolumn{1}{c|}{ Sig. } \\
\hline 1 & (Constant) & $1.7 \mathrm{E}+10$ & $2.1 \mathrm{E}+09$ & & 7.764 & .000 \\
& LABA_0 & .515 & .065 & .522 & 7.887 & .000 \\
\hline
\end{tabular}

Tabel 6

Model Summary

a. Predictors:

(Contant), LABA_0

Coefficients

a. Dependent Variable: CASH_1

\section{Kemampuan Prediksi Aliran Kas}

Tabel 7 menunjukkan hasil pengujian kemampuan prediksi aliran kas operasi terhadap aliran kas operasi masa depan. Hasilnya menunjukkan bahwa aliran kas operasi mempunyai kemampuan prediksi terhadap aliran kas operasi masa depan. Hal ini ditunjukkan melalui nilai Adjusted $\mathrm{R}^{2}$ sebesar $39,4 \%$ dan signifikan secara statistik (0.00).

Berdasarkan hasil analisis yang telah dipaparkan sebelumnya, maka hipotesis alternatif kedua yang menyatakan bahwa aliran kas operasi mempunyai kemampuan prediksi terhadap aliran kas operasi masa.depan terdukung.

\begin{tabular}{|l|r|r|r|r|}
\hline Model & $\mathrm{R}$ & R Square & $\begin{array}{c}\text { Adjusted } \\
\text { R Square }\end{array}$ & $\begin{array}{r}\text { Std. Error of } \\
\text { the Estimate }\end{array}$ \\
\hline 1 & $.631^{\mathrm{a}}$ & .398 & .394 & $2.452 \mathrm{E}+10$ \\
\hline
\end{tabular}

Tabel 7

Model Summary

a. Predictors:

(Contant), $\mathrm{CASH} 0$ 


\section{Daya \\ Prediksi \\ Laba dan \\ Aliran Kas}

Coefficients

a. Dependent Variable: CASH_1

Tabel 8

Model Summary

a. Predictors:

(Contant), LABA_0, CASH_0

Coefficients

a. Dependent Variable: CASH_1

\begin{tabular}{|c|c|c|c|c|c|c|}
\hline \multirow[b]{2}{*}{ Model } & & \multicolumn{2}{|c|}{$\begin{array}{l}\text { Unstandardized } \\
\text { Coefficients }\end{array}$} & \multirow{2}{*}{$\begin{array}{c}\begin{array}{c}\text { Standardized } \\
\text { Coefficients }\end{array} \\
\text { Beta } \\
\end{array}$} & \multirow[b]{2}{*}{$t$} & \multirow[b]{2}{*}{ Sig. } \\
\hline & & B & Std. Error & & & \\
\hline & (Constant) & $7.0 \mathrm{E}+09$ & $2.3 \mathrm{E}+09$ & & 3.091 & .002 \\
\hline & CASH_0 & .665 & .063 & .631 & 10.469 & .000 \\
\hline
\end{tabular}

\section{Perbandingan Kemampuan Prediksi Laba dan Aliran Kas}

Tabel 6 dan 7 menunjukkan hasil pengujian perbandingan kemampuan prediksi laba dan aliran kas operasi. Hasilnya menunjukkan bahwa aliran kas mempunyai kemampuan prediksi terhadap aliran kas operasi masa datang yang lebih baik dibandingkan dengan laba. Hal ini ditunjukkan melalui nilai Adjusted $\mathrm{R}^{2}$ laba yang lebih tinggi dibandingkan dengan aliran kas operasi $(27.3 \%>39,4 \%)$. Hal lain juga yang menjadi temuan adalah informasi laba dan aliran kas operasi mempunyai daya prediksi yang lebih tinggi apabila digunakan secara bersamasama. Hal ini ditunjukkan melalui nilai Adjusted $\mathrm{R}^{2}$ sebesar 43.3\% (Tabel 4.8).

Berdasarkan hasil analisis yang telah dipaparkan sebelumnya, maka hipotesis alternatif ketiga yang menyatakan bahwa laba mempunyai kemampuan prediksi terhadap aliran kas operasi masa datang yang lebih baik dibandingkan dengan aliran kas operasi tidak terdukung.

\begin{tabular}{|l|r|r|r|r|}
\hline Model & R & R Square & $\begin{array}{c}\text { Adjusted } \\
\text { R Square }\end{array}$ & $\begin{array}{c}\text { Std. Error of } \\
\text { the Estimate }\end{array}$ \\
\hline 1 & $.663^{\mathrm{a}}$ & .440 & .433 & $2.371 \mathrm{E}+10$ \\
\hline
\end{tabular}

\begin{tabular}{|c|c|c|c|c|c|c|}
\hline \multirow{2}{*}{\multicolumn{2}{|c|}{ Model }} & \multicolumn{2}{|c|}{$\begin{array}{l}\text { Unstandardized } \\
\text { Coefficients }\end{array}$} & \multirow{2}{*}{$\begin{array}{c}\begin{array}{c}\text { Standardized } \\
\text { Coefficients }\end{array} \\
\text { Beta } \\
\end{array}$} & \multirow[b]{2}{*}{$\mathrm{t}$} & \multirow[b]{2}{*}{ Sig. } \\
\hline & & $\mathrm{B}$ & Std. Error & & & \\
\hline \multirow[t]{3}{*}{1} & (Constant) & $8.2 \mathrm{E}+09$ & $2.2 \mathrm{E}+09$ & & 3.687 & .000 \\
\hline & CASH_0 & .519 & .074 & .493 & 7.027 & .000 \\
\hline & LABA_0 & .245 & .069 & .248 & 3.536 & .001 \\
\hline
\end{tabular}

\section{Analisa Hasil Penelitian}

Beberapa studi terdahulu menemukan bahwa laba memiliki daya prediksi yang tinggi terhadap aliran kas di masa yang akan datang. Laba merupakan salah satu informasi yang masih digunakan banyak pihak untuk melakukan fungsi prediksi. Hasil penelitian ini juga menunjukkan bahwa informasi laba masih memiliki kemampuan prediksi yang kuat terhadap aliran kas operasi masa depan. Hasil ini konsisten dengan hasil penelitian Greenberg et al. (1986), Finger (1994), Lorek dan Willinger (1996), Cheng et al. (1996), Burgstahler et al. (1998), Supriyadi (1999), DeFond dan Hung (2001), Kim dan Kross (2002) menemukan bahwa laba mempunyai kemampuan prediksi yang baik terhadap aliran kas masa depan.

Selain informasi laba, informasi aliran kas juga sering digunakan banyak pihak untuk melakukan fungsi prediksi. Beberapa studi juga menemukan bahwa aliran kas operasi memiliki daya prediksi yang tinggi terhadap aliran kas di masa depan. Hasil penelitian ini juga menunjukkan hasil yang sama. Hasil ini konsisten dengan penelitian Bowen et al. (1986), Finger (1994), Cheng et al. (1996), Burgstahler et al. (1998), Supriyadi (1999), DeFond dan Hung (2001), Kusuma (2003), Riyanto (2004), Bandi dan Rahmawati (2005) menemukan bahwa aliran kas merupakan prediktor yang baik terhadap aliran kas masa depan.

Kemudian penelitian ini menunjukkan bahwa aliran kas memiliki kemampuan prediksi terhadap aliran kas operasi di masa depan yang lebih dibandingkan dengan laba. Hasil ini konsisten dengan penelitian Bowen et al. (1986), Finger (1994), Burgstahler et al. (1998), DeFond dan Hung (2001) yang menemukan bahwa aliran kas dapat memprediksi aliran kas masa depan lebih baik dibandingkan laba. Hal ini terjadi dikarena laba akuntansi yang digunakan adalah laba agregat. laba agregat menutupi kemampuan komponen-komponen laba dalam memprediksi aliran kas masa depan (Barth et al. ,2001). 
Selain itu, penelitian ini juga menemukan bahwa informasi laba dan aliran kas secara bersama-sama dapat menjadi prediktor yang lebih baik dibandingkan informasi ini digunakan secara terpisah. Jadi kedua informasi ini lebih baik digunakan secara bersama-sama untuk memprediksi aliran kas di masa depan.

\section{Simpulan}

Hasil penelitian menunjukkan bahwa baik laba maupun aliran kas operasi sekarang mempunyai kemampuan prediksi yang baik terhadap aliran kas masa depan. Aliran kas operasi sekarang terbukti memiliki kemampuan prediksi yang lebih baik dibandingkan laba terhadap aliran kas operasi masa depan. Laba dan aliran kas operasi sekarang secara bersama-sama memiliki kemampuan prediksi yang lebih baik dibandingkan informasi ini digunakan secara parsial. Jadi kedua informasi ini harus digunakan secara bersama-sama untuk melakukan fungsi prediksi.

Keterbatasan dalam penelitian ini adalah Peneliti tidak menguji kemampuan prediksi laba, aliran kas, dan komponen-komponen laba terhadap aliran kas masa depan. Sehingga saran untuk riset selanjutnya adalah melakukan uji terhadap kemampuan prediksi laba, aliran kas, dan komponen-komponen laba.

\section{Daftar Pustaka}

Almilia, L. S. dan Sulistyowati, D. 2007. "Analisis terhadap Relevansi Nilai Laba, Arus Kas Operasi, dan Nilai Buku Ekuitas Pada Periode di Sekitar Krisis Keuangan Pada Perusahaan Manufaktur di BEJ". Proceeding Seminar Nasional. FE Universitas Trisakti. Jakarta.

Bandi, dan Rahmawati. 2005. "Relevansi Kandungan Informasi Komponen Arus Kas dan Laba dalam Memprediksi Arus Kas Masa Depan”. Jurnal Akuntansi \& Bisnis, Vol. 5. No. 1, 27-42.

Barth, M. E., Donald P. C. dan Karen K. N. 2001. "Accruals and the Prediction of Future Cash Flows". The Accounting Review. Vol. 76, pp. 27-58.

Boulding, W. dan A. Kirmani. 1992. "A Consumer-Side Experimental Examination of Signaling Theory: Do Consumers Perceive Warranties as Signals of Quality?". Journal of Consumer Research. pp. 111-123.

Bowen, R. M., David B., dan Lane A. D.. 1986. "Evidence on The Relationship Between Earnings and Various Measures of Cash Flows". The Accounting Review. (LXI) No. 4, pp. 713-725.

Burgstahler, D., J. Jiambalvo dan Y. Pyo,. 1998. "The Informativeness of Cash Flows for Future Cash Flows". Working Paper. University of Washington.

Cahyadi, R. 2006. "Kemampuan Earnings dan Arus Kas dalam Memprediksi Earnings dan Arus Kas di Masa yang Akan Datang". Thesis. Fakultas EkonomiUniversitas Islam Indonesia. Yogyakarta.

Cheng, C.S.A., C.S. Liu, dan T.F. Schaefer. 1996. "Earnings Permanence and the Incremental Information Content of Cash Flows from Operations". Journal of Accounting Research. Vol. 34. No.1, Spring, 173-181.

Dahler, Y. dan R. Febrianto. 2006. "Kemampuan Prediktif Earnings dan Arus Kas dalam Memprediksi Arus Kas Masa Depan”. Simposium Nasional Akuntansi 9. Padang.

Dechow, P.M., S.P. Kothari dan R.L. Watts. 1998. “The Relation Between Earnings and Cash Flows". Journal of Accounting and Economics 25. pp. 133-168.

DeFond, Mark dan M.Y.Hung. 2001. An Empirical Analysis of Analysts' Cash Flow Forecast. SSRN.

Eldomiaty, T. I. 2004. "Dynamics of Financial Signaling Theory and Systematic Risk Classes in Transitional Economies: Egyptian Economy in Perspective". Journal of Financial Management and Analysis. pp. 41-59. 


\section{Daya \\ Prediksi \\ Laba dan \\ Aliran Kas}

FASB. 1987. Statement of Financial Accounting Concepts (SFAC) No. 1.

Finger, C. A. 1994. "The Ability of Earnings to Predict Future Earnings and Cash Flow". The Journal Accounting Research. Vol. 32, No.2, Autumn. pp. 210223.

Gee-Jung, Kwon. "The Value Relevance of Book Values, Earnings and Cashflows: Evidence from Korea. 2009". International Journal of Business and Management. Vol.4, No.10.

Ghozali, H. I. 2006. Aplikasi Analisis Multivariate dengan Program SPSS. Badan Penerbit Universitas Diponegoro. Semarang.

Greenberg, R.R., G.L. Johnson dan K. Ramesh. 1986. "Earnings versus Cash Flow as a Predictor of Future Cash Flow Measures". Journal of Accounting, Auditing, and Finance. pp. 266-277.

Hair, J.E. Jr. R. E., Anderson, R. L. Tatham dan W. C. Black, 1998. Multivariate Data Analysis, Prentice-Hall International. Inc., New Jersey.

Hendriksen ES., dan Van Breda MF., 1992. Accounting Theory, 5th Edition, Irwin, Homewood, Boston.

Jones, R. dan A. J. Murrel. 2001. "Signaling Positive Corporate Social Performance". Business and Society. pp. 59-78.

Kim, M. S. dan W. Kross. 2002. "The Ability of Earnings to Predict Future Operating Cash Flows Has Been Increasing - Not Decreasing". SSRN.

Kusuma, P. D. I.. 2003. "Nilai Tambah Kandungan Informasi Laba dan Arus Kas Operasi". SNA VI, hal. 304-315.

Landsman, W. \& Maydew, A. (2002). "Has The Information Content of Quarterly Earnings Announcements Declined In The Past Three Decades?". Journal of Accounting Research, 40 (3), 797-808.

Lorek, Kenneth S. dan Willinger, G. Lee. 1996. "A Multivariate Time-Series Prediction Model for Cash-Flow Data". The Accounting Review. Vol. 71, No.1, pp.81-101.

Lorek, Kenneth S. dan Willinger, G. Lee. 2002. "An Analysis of The Accuracy of Long-Term Earnings Predictions". Advances in Accounting. Vol.19, pages 161175.

Rayburn, J. 1986. "The Association of Operating Cash Flow and Accruals with Security Returns". Journal of Accounting Research 24 (Supplement): 112-133.

Riyanto, P. 2004. "Penggunaan Laba dan Komponen Arus Kas untuk Memprediksi Laba dan Arus Kas pada Perusahaan Manufaktur di Pasar Modal Indonesia Periode Tahun 1999-2002”. Thesis. Program Studi Magister Akuntansi. Universitas Diponegoro. Semarang.

Sloan, R. G. 1996. "Do Stock Prices Fully Reflect Information in Accruals and Cash Flows About Future Earnings?". The Accounting Review 71: 289-315.

Supriyadi. 1999. "The Predictive Ability of Earnings Versus Cash Flow Data to Predict Future Cash Flows: A Firm-Specific Analysis". Gadjah Mada International Journal of Business. Vol. 1, September, h. 113-132.

Suwardjono. 2005. Teori Akuntansi-Perekayasaan Pelaporan Keuangan. Edisi Ketiga. Yogyakarta: BPFE.

Watson, J. dan Wells, P. 2005. "The Association Between Various Earnings and Cashflow Measures of Firm Performance and Stock Return: Some Australian Evidence". The AFAANZ Conference. Melbourne.

Wilson, G.P. 1986. "The Relative Information Content of Accruals and Cash Flows: Combine Evidence At The Earnings Announcement and The Annual Reports Release Date". Journal of Accounting Research 24 (Supplement): 165-200. 